\title{
Kelangsungan Penggunaan Kontrasepsi di Indonesia
}

\author{
Sariana Sistri*
}

\begin{abstract}
Abstrak
Indonesia merupakan negara dengan jumlah penduduk terbesar keempat di dunia setelah Republik Rakyat Cina, India dan Amerika Serikat. Pada periode 2000-2002, penduduk Indonesia meningkat 1,25\% atau 7,3 juta setiap tahun, sehingga pada tahun 2002 jumlah penduduk Indonesia menjadi sekitar 215 juta jiwa. Berdasarkan data SDKI, Total Fertility Rate (TFR) tahun 1997 (2,8) dan 2003 (2,6), dalam kurun waktu dua dasawarsa. Contraceptive Prevalence Rate (CPR), di Indonesia, pada 1977 (26) meningkatan dua kali lipat pada tahun 1997 (57) Penelitian ini bertujuan untuk mengetahui kelangsungan pemakaian kontrasepsi sejak pertama kali pemakaian pada periode 1997-2002, berikut berbagai faktor yang berhubungan. Desain penelitian yang digunakan adalah kohort retrospektif, dengan analisis survival, regresi cox. Sumber data yang digunakan adalah data sekunder SDKI 2002-2003, dengan jumlah sampel 5.072 kepala keluarga. Dari penelitian ini didapatkan lama kelangsungan pemakaian kontrasepsi pada periode 1997-2002 di Indonesia sejak pertama kali pakai hingga pemakaian 72 bulan adalah 50,32\%. Faktor-faktor yang berhubungan dengan kelangsungan pengunaan kontrasepsi adalah tingkat pendidikan ibu dan status pekerjaan ibu.
\end{abstract}

Kata kunci : Kelangsungan penggunaan kontrasepsi, determinan

\begin{abstract}
It has been known that Indonesia is the fourth largest population in the world, after People Republic of China, India, and United States. At the year of 2002, Indonesia total population is about 215 million, with a growth rate between 2000 and 2002 is about $1.25 \%$ meaning that there is about 7.3 million people every year. The success of the Family Planning Program is recognized by its indicators, namely Total Fertility Rate (TFR) and Contraceptive Prevalence Rate (CPR). The TFR at SDKI 1997 was 2.8 and in SDKI 2003 was 2.6. While CPR, in two decades has increased double fold from 26 in 1977 to 57 in 1997. The study is carried out in order to know the length of continuation on contraceptive use since the first time of using, in the period of 1997-2002 and related factors. The design is cross sectional with retrospective cohort, using survival analysis technique. Data is secondary data of SDKI 2002-2003 on 5,072 samples. The results of the study showed that contraceptive continuation since it first use until 72 months follow up period is $50.32 \%$. Factors related to the continuation are level of education and occupation of the mother.
\end{abstract}

Key words : Contraceptive use, determinant 
Jumlah penduduk Indonesia yang terbesar keempat didunia setelah Republik Rakyat Cina, India dan Amerika Serikat. ${ }^{1}$ Pada tahun 2002 jumlah penduduk Indonesia sekitar 215 juta jiwa dengan laju pertumbuhan penduduk antara tahun 2000-2002 sekitar 1,25\%, maka terjadi penambahan penduduk sekitar 7,3 juta setiap tahunnya. ${ }^{2}$ Jika laju pertumbuhan penduduk tersebut tidak terkendali, diperkirakan jumlah penduduk Indonesia akan bertambah 43 juta jiwa dalam 10 tahun mendatang. Data tersebut menunjukkan besarnya jumlah penduduk Indonesia akibat angka pertumbuhan penduduk yang tinggi sehubungan dengan tingkat kelahiran yang tinggi. ${ }^{3}$ Dengan perkembangan perekonomian masyarakat, peningkatan pendidikan dan perubahan pandangan hidup tentang nilai anak, gerakan Keluarga Berencana Nasional diarahkan untuk menetapkan kualitas keluarga. Kualitas tersebut bercirikan kemandirian ketahanan keluarga dalam mewujudkan keluarga kecil yang bahagia dan sejahtera. ${ }^{4}$

Selama ini upaya yang dilakukan pemerintah untuk mencapai keluarga sejahtera adalah melalui program Keluarga Berencana (KB) yang mulai dilaksanakan secara resmi pada awal tahun 1970-an. Hal tersebut merupakan upaya pemerintah mengatasi pertambahan penduduk yang semakin pesat dan dikenal sebagai salah satu program yang paling berhasil di dunia. ${ }^{5}$ Keberhasilan program KB ini dapat dilihat dari dua indikator yang meliputi angka prevalensi kontrasepsi (Contraceptive Prevalence Rate/CPR) dan angka ratarata penurunan jumlah anak yang dilahirkan (Total Fertility Rate/TFR). ${ }^{5}$ Dalam kurun waktu dua dasawarsa Indonesia mengalami peningkatan CPR dua kali lipat dari tahun 1977 (26) sampai tahun 1997 (57). Total Fertility Rate (TFR) menunjukkan rata-rata jumlah anak yang dilahirkan. Berdasarkan data SDKI diketahui TFR 1991 (3), 1994 (2,9), 1997 (2,8) dan 2003 $(2,6)$ memperlihatkan kecenderungan yang terus menurun. ${ }^{2}$

Upaya pengendalian fertilitas dilakukan melalui peningkatan kegiatan penyampaian pesan kepada seluruh lapisan masyarakat. Hal tersebut dilakukan untuk meningkatkan pengetahuan, mengubah sikap dan perilaku menerima dan mempraktekkan Keluarga Berencana. Semakin terlihat bahwa upaya tersebut berhasil mengajak para wanita yang berumur 15-49 tahun dengan status kawin untuk menjadi akseptor KB. ${ }^{5}$ Data SDKI 2002-2003 diketahui bahwa pemakaian kontrasepsi di Indonesia pada wanita dengan status kawin meningkat sebesar 3\% dari tahun 1997 (57\%) menjadi $2003(60 \%)$. Data Susenas dalam Statistik Kesejahteraan Rakyat 2004 menyebutkan bahwa dari wanita usia 15-49 tahun yang berstatus kawin yang sedang memakai alat KB adalah 56,71\%.

Beberapa faktor sosial ekonomi dan faktor de- mografi dapat mempengaruhi penggunaan kontrasepsi. Faktor sosial, ekonomi antara lain meliputi keterlibatan dalam organisasi, norma dan hukum, pendapatan, kebiasaan, agama dan tempat pelayanan. Sedangkan faktor demografi antara lain meliputi karakteristik individu seperti umur, status perkawinan, pendidikan, lama perkawinan dan pekerjaan. ${ }^{6}$ Ada banyak faktor yang menyebabkan ketidaklangsungan pemakaian kontrasepsi antara lain meliputi jenis alat yang digunakan, efek samping, kegagalan alat, keinginan punya anak, sosial ekonomi dan motivasi ibu untuk melaksanakan KB.

Penelitian ini bertujuan mengetahui lama kelangsungan pemakaian alat kontrasepsi sejak pertama kali memakai dalam periode pengamatan tahun 1997-2002 dan faktor-faktor yang berhubungan dengan kelangsungan pemakaian kontrasepsi di Indonesia. Faktorfaktor yang diuji meliputi umur responden, jumlah anak, tempat tinggal, pendidikan ibu, pekerjaan ibu, pekerjaan suami, tingkat ekonomi keluarga, kunjungan petugas, tempat pelayanan untuk mendapatkan kontrasepsi, kunjungan ibu ke tempat pelayanan kesehatan.

\section{Metode}

Penelitian ini menggunakan sumber data sekunder Survei Demografi dan Kesehatan Indonesia 2002-2003 yang dikumpulkan oleh BKKBN, BPS, Depkes RI dan Macro International Inc. Survei yang berskala nasional tersebut dilaksanakan pada bulan Oktober 2002 sampai dengan April 2003. Desain pada penelitian ini adalah desain kohort restrospektif dengan lama penggunaan kontrasepsi dijadikan variabel masa pengamatan. Populasi pada penelitian ini adalah wanita Indonesia berusia 1549 tahun, berstatus kawin yang menggunakan alat kontrasepsi. Sampel pada penelitian ini adalah wanita kawin yang menggunakan alat/metode kontrasepsi untuk pertama kali dalam periode 1997-2002. Untuk kebutuhan analisis, diperlukan jumlah sampel minimal yang harus dipenuhi sebanyak 1.607 yang didapat dari perhitungan sampel dengan menggunakan rumus sampel disain studi kohort. ${ }^{7}$ Variabel yang diteliti adalah variabel-variabel umur, jumlah anak, tempat tinggal, tingkat pendidikan, status bekerja, pekerjaan suami, tingkat sosial ekonomi, kunjungan petugas KB sebagai variabel independen, dan kelangsungan penggunaan kontrasepsi sebagai variabel dependen.

\section{Hasil}

Probabilitas kumulatif kelangsungan penggunaan kontrasepsi yang paling lama adalah 72 bulan sebanyak $50,35 \%$ dari seluruh responden, artinya dari 100 orang wanita yang menggunakan kontrasepsi untuk pertama kalinya dalam periode 1997-2002 hanya 50 orang yang dapat bertahan hingga 72 bulan. 


\begin{tabular}{|c|c|c|c|c|c|}
\hline Variabel & Katagori & $\mathbf{N}$ & $\%$ & Median Time & $\begin{array}{l}\text { Probabilitas } \\
\text { Kelangsungan (\%) }\end{array}$ \\
\hline \multirow[t]{3}{*}{ Umur } & $>35$ & 187 & 3,7 & 65 & 20,09 \\
\hline & $20-35$ & 4.059 & 80,0 & & 43,30 \\
\hline & $15-19$ & 827 & 16,3 & & 26,06 \\
\hline \multirow[t]{2}{*}{ Anak } & $>2$ & 1.077 & 21,2 & 70 & 47.98 \\
\hline & $\leq 2$ & 3.996 & 78,8 & & 49,52 \\
\hline \multirow[t]{2}{*}{ Tempat Tinggal } & Desa & 2.707 & 53,3 & 70 & 50,75 \\
\hline & Kota & 2.371 & 46,7 & & 47,70 \\
\hline \multirow[t]{3}{*}{ Pendidikan } & $\geq$ SMA & 403 & 7,9 & 70 & 57,41 \\
\hline & SMP & 2.571 & 50,7 & & 52,67 \\
\hline & $<$ SMP & 2.099 & 41,4 & & 43,65 \\
\hline \multirow[t]{2}{*}{ Pekerjaan Ibu } & Bekerja & 2.522 & 49,7 & 68 & 48,22 \\
\hline & Tidak Bekerja & 2.551 & 50,3 & & 50,78 \\
\hline \multirow[t]{4}{*}{ Pekerjaan Ayah } & Tidak Kerja & 871 & 16,1 & 70 & 41,97 \\
\hline & Teknisi & 714 & 14,1 & & 57,56 \\
\hline & Dagang & 1.296 & 26,5 & & 52,67 \\
\hline & Tani & 2.245 & 44,3 & & 47,56 \\
\hline \multirow[t]{3}{*}{ Ekonomi Keluarga } & Miskin & 2.025 & 39,9 & 70 & 50,43 \\
\hline & Menengah & 1.015 & 20,0 & & 49,83 \\
\hline & Kaya & 2.033 & 40,1 & & 48,27 \\
\hline \multirow[t]{2}{*}{ Kunjungan Petugas } & Ya & 329 & 6,5 & 69 & 40,56 \\
\hline & Tidak & 4.744 & 93,5 & & 50,22 \\
\hline \multirow{3}{*}{ Fasilitas Kesehatan } & Swasta & 2.853 & 56,2 & 70 & 50,14 \\
\hline & Pemerintah & 943 & 18,6 & & 42,72 \\
\hline & Lain-lain & 1.277 & 25,2 & & 54,16 \\
\hline \multirow[t]{2}{*}{ Kunjungan Yankes } & Ya & 2.451 & 48,3 & 70 & 51,53 \\
\hline & Tidak & 2.622 & 51,7 & & 47,32 \\
\hline
\end{tabular}

\section{Analisis Univariat}

Responden terbanyak menggunakan kontrasepsi berumur 20-35 tahun (80\%) dengan median time 65 bulan. Responden yang pertama kali menggunakan kontrasepsi mempunyai $\leq 2$ anak adalah 3.996 orang $(78,8 \%)$ dengan probabilitas penggunaan $(49,52 \%)$, yang mempunyai anak $>2$ adalah 1,070 orang $(21,2 \%)$ dengan probabilitas kelangsungan penggunaan $(47,98 \%)$. Responden bermukim di desa $(53,3 \%)$ lebih besar daripada di kota $(46,7 \%)$. Namun, persalinan pada pengguna kontrasepsi lebih banyak di kota $(>50 \%)$ median time kelangsungan penggunaan kontrasepsi di pedesaan adalah 70 bulan dengan probabilitas kelangsungan penggunaan sampai 72 bulan $(47,70 \%)$ lebih rendah daripada yang di perkotaan $(50,75 \%)$. Responden berpendidikan SMP $(50,7 \%)$ merupakan yang tertinggi. Median time responden berpendidikan < SMP (70 bulan). Probabilitas kelangsungan penggunaan hingga 72 bulan untuk responden berpendidikan SMP $(52,67 \%),<$ SMP $(43,65 \%)$ dan $\geq \operatorname{SMP}(57,41 \%)$. Responden bekerja $(49,7 \%)$ dengan probabilitas kelangsungan penggunaanhingga 72 bulan $(48,22 \%)$ lebih rendah daripada yang tidak bekerja $(50,3 \%)$ dengan probabilitas kelangsungan pemakaian $(50,78 \%)$. Pekerjaan suami yang terbanyak adalah tani buruh dengan median time kelangsungan penggunaan 70 bulan dan probabilitas kelangsungan hingga 72 bulan $(47,56 \%)$. Responden terbanyak berasal dari keluarga kaya $(40,1 \%)$ dengan probabilitas kelangsungan hingga 72 bulan $(48,27 \%)$. Responden yang dikunjungi petugas KB $(93,5 \%)$ dengan median time (69 bulan) dengan probabilitas kelangsungan penggunaan $(40,56 \%)$ lebih kecil daripada yang tidak dikunjungi $(50,22 \%)$. Responden pengunjung fasilitas kesehatan pemerintah $(18,6 \%)$ lebih kecil daripada fasilitas kesehatan swasta $(56,2 \%)$ dan fasilitas yang lain $(25,2 \%)$. Median time responden yang berkunjung ke fasilitas pemerintah (70 bulan) dengan probabilitas kelangsungan penggunaan hingga 72 bulan $(42,72 \%)$ lebih rendah daripada yang berkunjung ke fasilitas kesehatan swasta $(50,14 \%)$ dan yang lain $(54,16 \%)$ (Lihat Tabel 1$)$.

\section{Analisis Bivariat}

Analisis bivariat yang dilakukan dengan metode regresi cox dan crosstabs bertujuan untuk menentukan variabel kandidat yang akan masuk ke dalam analisis multivariat regresi cox. Variabel yang memenuhi kriteria kandidat model multivariat (nilai $\mathrm{p}<0,25$ ) adalah jumlah anak, pendidikan, status pekerjaan ibu, jenis pekerjaan suami, tingkat ekonomi keluarga (Lihat Tabel 2).

\section{Analisis Multivariat}

Analisis multivariat dilakukan untuk mendapatkan 
Tabel 2. Hasil Analisis Bivariat

\begin{tabular}{|c|c|c|}
\hline Variabel & Katagori & Nilai p \\
\hline Umur & $\begin{array}{l}>35 \\
20-35 \\
15-19\end{array}$ & 0,78 \\
\hline Anak & $\begin{array}{l}>2 \\
\leq 2\end{array}$ & 0,09 \\
\hline Tempat Tinggal & $\begin{array}{l}\text { Desa } \\
\text { Kota }\end{array}$ & 0,84 \\
\hline Pendidikan & $\begin{array}{l}\geq \text { SMA } \\
\text { SMP } \\
<\text { SMP }\end{array}$ & 0,09 \\
\hline Pekerjaan Ibu & $\begin{array}{l}\text { Bekerja } \\
\text { Tidak Bekerja }\end{array}$ & 0,01 \\
\hline Pekerjaan & $\begin{array}{l}\text { Ayah Tidak Kerja } \\
\text { Teknisi } \\
\text { Dagang } \\
\text { Tani }\end{array}$ & 0,19 \\
\hline Ekonomi Keluarga & $\begin{array}{l}\text { Miskin } \\
\text { Menengah } \\
\text { Kaya }\end{array}$ & 0,04 \\
\hline Kunjungan Petugas & $\begin{array}{l}\text { Ya } \\
\text { Tidak }\end{array}$ & 0,30 \\
\hline Fasilitas Kesehatan & $\begin{array}{l}\text { Swasta } \\
\text { Pemerintah } \\
\text { Lain-lain }\end{array}$ & 0,92 \\
\hline Kunjungan Yankes & $\begin{array}{l}\text { Ya } \\
\text { Tidak }\end{array}$ & 0,94 \\
\hline
\end{tabular}

Tabel 3. Seleksi Model Dasar Multivariat

\begin{tabular}{llll}
\hline Variabel & Katagori & Hazard Rasio & Nilai p \\
\hline Anak & $>2$ & 1,1 & 0,285 \\
\multirow{2}{*}{ Pendidikan } & $\leq 2$ & & \\
& $\geq$ SMA & 1 & \\
SMP & 1,29 & 0,073 \\
Pekerjaan Ibu & $<$ SMP & 1,26 & 0,117 \\
Pekerjaan Ayah & Bekerja & 1,17 & 0,023 \\
& Tidak Bekerja & & \\
& Tidak Kerja & 1 & \\
& Teknisi & 0,81 & 0,102 \\
Ekonomi Keluarga & Dagang & 0,95 & 0,644 \\
& Tani & 0,90 & 0,299 \\
& Miskin & 1 & \\
& Menengah & 0,88 & 0,195 \\
& Kaya & 1,09 & 0,213 \\
\hline
\end{tabular}

model prediksi variabel yang berpengaruh terhadap kelangsungan penggunaan kontrasepsi di Indonesia. Pemeriksaan asumsi yang dilakukan menggunakan uji Goodness Of Fit (GOF). Hasil uji asumsi dengan menggunakan Goodness Of Fit (Global test) diketahui bahwa seluruh variabel $(\mathrm{p}>0,05)$ yang merupakan kandidat variabel yang berhubungan dengan kelangsungan penggunaan kontrasepsi, kecuali variabel jumlah anak ( $\mathrm{p}=$ $0,03)$. Variabel yang valid dalam model multivariat adalah yang mempunyai nilai $\mathrm{p}<0,05$, bila dari hasil analisis ada variabel yang memiliki nilai $\mathrm{p}>0,05$ maka harus dikeluarkan dari pemodelan dimulai dari variabel yang memiliki nilai p yang paling besar. Variabel yang
Tabel 4. Model Multivariat Akhir

\begin{tabular}{llccc}
\hline Variabel & Katagori & Koefisien & Hazard Rasio & Nilai p \\
\hline Pendidikan & $\geq$ SMA & & 1 & \\
& SMP & 0,29 & 1,34 & 0,034 \\
& < SMP & 0,28 & 1,30 & 0,059 \\
Pekerjaan Ibu & Bekerja & & & \\
& Tidak Bekerja & 0,16 & 1,18 & 0,014 \\
\hline
\end{tabular}

memiliki nilai $\mathrm{p}$ yang paling besar jika dikeluarkan merubah hilai hazard rasio $>10 \%$ maka variabel ini harus dimasukkan kembali ke dalam pemodelan, namun jika perubahan nilai hazard rasio $<10 \%$ variabel ini tetap harus dikeluarkan dari pemodelan. Urutan pengeluaran variabel dimulai dari variabel anak, status ekonomi keluarga, jenis pekerjaan suami. Setelah ketiga variabel tersebut dikeluarkan satu persatu ternyata tidak merubah nilai $\mathrm{HR}$ variabel yang lainnya $>10 \%$, maka ketiga variabel tersebut harus dikeluarkan dari pemodelan multivariat (Lihat Tabel 3).

Model akhir yang dapat menjelaskan faktor yang berhubungan dengan kelangsungan penggunaan kontrasepsi ada dua variabel yaitu pendidikan ibu dan status pekerjaan ibu (Lihat Tabel 4).

Persamaan model akhir dari faktor yang berhubungan dengan lama kelangsungan penggunaan kontrasepsi adalah :

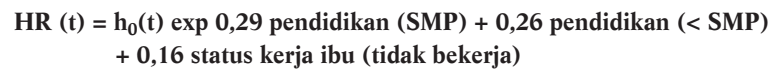

Interpretasi persamaan model adalah ibu dengan tingkat pendidikan SMP maka risiko untuk putus memakai kontrasepsi sebesar 1,34 kali lebih besar bila dibandingkan dengan ibu dengan tingkat pendidikan SMA atau lebih tinggi dari SMA. Ibu dengan tingkat pendidikan $<$ SMP maka risiko untuk putus memakai kontrasepsi sebesar 1,30 kali lebih besar bila dibandingkan dengan ibu dengan tingkat pendidikan SMA atau lebih tinggi dari SMA. Sedangkan, ibu yang tidak bekerja mempunyai risiko untuk putus memakai kontrasepsi 1,18 kali lebih besar bila dibandingkan dengan ibu yang bekerja.

\section{Pembahasan \\ Keterbatasan Penelitian}

Penelitian ini mempunyai banyak keterbatasan antara lain adalah menggunakan sumber data sekunder survei yang bersifat cross sectional, artinya setiap sampel hanya diamati satu kali selama penelitian berlangsung. Sementara analisis yang dilakukan seharusnya memerlukan pengamatan berkelanjutan seperti pada rancangan kohort. Selain itu, karena menggunakan desain potong lintang maka penelitian ini tidak dapat menghindari recall bias yang mungkin terjadi karena responden lupa 
dengan kejadian yang pernah terjadi. Data 2002-2003 menggunakan desain sampel yang komplek. Semestinya dalam analisis dilakukan pembobotan, klaster dan juga memperhatikan PSU, akan tetapi karena keterbatasan software yang digunakan untuk analisis data maka analisis ini tidak mempertimbangkan desain sampel.

Hasil penelitian menunjukkan bahwa probabilitas ibu untuk terus-menerus menggunakan kontrasepsi semakin lama semakin menurun, hal ini terlihat dari hasil analisis mengenai kelangsungan penggunaan kontrasepi. Dalam waktu pengamatan selama 6 tahun (1997-2002) diketahui kelangsungan penggunaan kontrasepsi paling lama adalah selama 72 bulan penggunaan yang dihitung dari sejak pertama kali menggunakan kontrasepsi. Berdasarkan 5.072 sampel yang bertahan kelangsungan penggunaan kontrasepsinya hingga 72 bulan sebanyak $59 \%$. Kelangsungan penggunaan kontrasepsi yang rendah ini disebabkan oleh banyak faktor, sehingga apabila tidak diatasi dikhawatirkan jumlah penduduk akan terus bertambah, yang dapat mengakibatkan masalah diberbagai segi kehidupan.

\section{Determinan}

Banyak penelitian yang sudah dilakukan sebelumnya diketahui ada banyak faktor yang mempengaruhi kelangsungan penggunaan kontrasepsi, namun dari hasil analisis yang dilakukan dalam penelitian ini hanya ada dua faktor saja yang mempengaruhinya yaitu tingkat pendidikan dan status pekerjaan ibu.

Tingkat pendidikan yang pernah ditempuh ibu ternyata mempengaruhi kelangsungan penggunaan kontrasepsi. Responden dengan tingkat pendidikan terbanyak adalah pendidikan menengah hingga tinggi. Hasil tersebut sesuai dengan penelitian Yayasan Kusuma Buana (1998) tentang ciri-ciri dari akseptor IUD yang berpendidikan tinggi. Probabilitas kelangsungan penggunaankontrasepsi hingga 72 bulan untuk ibu yang memiliki tingkat pendidikan SMP atau > SMP mencapai lebih dari $50 \%$, sedangkan yang memiliki tingkat pendidikan < SMP memiliki tingkat kelangsungan penggunaan kontrasepsi hingga 72 bulan hanya sebanyak 43,65\%. Semakin tinggi tingkat pendidikan ibu diharapkan semakin baik kelangsungan penggunaan kontrasepsi.

Proporsi ibu yang bekerja dan ibu yang tidak bekerja hampir sama. Berdasarkan analisis multivariat juga diketahui bahwa status pekerjaan ibu berpengaruh terhadap kelangsungan penggunaan kontrasepsi. Probabilitas kelangsungan penggunaan kontrasepsi hingga 72 bulan untuk ibu yang bekerja atau tidak bekerja tidak jauh berbeda, risiko untuk gagal mempertahankan kelangsungan penggunaan kontrasepsi pada ibu yang tidak bekerja 1,18 kali lebih besar daripada ibu yang bekerja. Hasil penelitian ini senada dengan penelitian yang telah dilakukan di Indonesia sebelumnya bahwa ada hubungan yang bermakna antara pekerjaan responden dengan kelangsungan penggunaan kontrasepsi. ${ }^{8}$ Diharapkan kelangsungan penggunaan kontrasepsi ibu yang bekerja lebih lama daripada ibu yang tidak bekerja.

Seluruh responden yang diamati, lebih dari separuh yang berusia $20-35$ tahun (80\%) dengan probabilitas kelangsungan penggunaan kontrasepsi $48,30 \%$, sisanya $16,3 \%$ berusia $<20$ tahun dengan tingkat kelangsungan penggunaan kontrasepsinya $(26,06 \%)$ dan yang berusia $>35$ tahun $(3,7 \%)$ dengan tingkat probabilitas kelangsungan penggunaan kontrasepsi $(26,06 \%)$. Tidak ada hubungan yang bermakna antara umur ibu dengan kelangsungan penggunaan kontrasepsi di Indonesia dalam periode waktu 1997-2002. Hal tersebut mungkin dipengaruhi oleh umur responden yang berkisar antara 20 hingga 35 tahun yang merupakan usia paling baik untuk hamil dan melahirkan.

Sebagian besar responden memiliki anak dua orang atau kurang $(78,8 \%)$. Probabilitas kelangsungan penggunaan kontrasepsi $(49,52 \%)$ dan hanya $21,2 \%$ responden yang telah mempunyai anak lebih dari dua orang dengan tingkat kelangsungan penggunaan kontrasepsi $47,98 \%$. Namun, jumlah anak ternyata tidak berpengaruh terhadap kelangsungan penggunaan kontrasepsi, hal ini mungkin disebabkan oleh keluarga berencana bukan bertujuan untuk menghentikan kehamilan, tetapi untuk menunda kehamilan serta mengatur jarak kehamilan. Hal ini bertentangan dengan motto keluarga berencana saat ini yaitu 2 anak lebih baik, sehingga diharapkan dapat tercipta keluarga yang berkualitas.

Tidak ada hubungan bermakna antara tempat tinggal responden dengan kelangsungan pemakaian kontrasepsi. Proporsi penyebaran penduduk antara kota dan desa hampir merata demikian juga dengan probabilitas kelangsungan penggunaan kontrasepsi hingga 72 bulan antara kota dan desa tidak terlalu berbeda. Probabilitas kelangsungan penggunaan kontrasepsi untuk responden yang tinggal di desa $(48,22 \%)$ lebih rendah daripada responden yang tinggal di kota $(50,75 \%)$. Hasil penelitian ini tidak sesuai dengan penelitian sebelumnya yang menemukan ketertarikan pada kontrasepsi jika dilihat dari promosi, ibu-ibu di desa lebih besar daripada di kota. ${ }^{8}$ Sementara itu, Pratomo mengatakan bila tempat tinggal dikaitkan dengan paparan promosi tentang kontrasepsi di kota lebih besar daripada di desa. Namun pada penelitian ini tidak membahas keterpaparan media, sehingga tidak dapat diketahui apakah tempat tinggal dan media promosi berhubungan dengan kelangsungan penggunaan kontrasepsi.

Sebagian besar responden memiliki suami yang bekerja, tetapi pekerjaan suami tidak mempengaruhi kelangsungan penggunaan kontrasepsi. Walau demikian, proporsi kelangsungan penggunaan kontrasepsi pada ibu yang memiliki suami yang tidak bekerja lebih tinggi 1,01 
daripada ibu yang memiliki suami yang bekerja. Sebagian besar responden memiliki suami yang bekerja sebagai tani/buruh yaitu sebanyak 44,3\% dan yang paling sedikit responden yang memiliki suami yang bekerja sebagai teknisi/administrasi yaitu $14,1 \%$, namun memiliki probabilitas yang lebih tinggi dalam kelangsungan penggunaankontrasepsi hingga 72 bulan pemakaian dibandingkan dengan responden yang memiliki jenis pekerjaan yang lain, yaitu sebesar 57,56\%.

Sebagian besar responden mengatakan tidak pernah dikunjungi oleh petugas keluarga berencana, hasil uji menunjukkan tidak ada hubungan kelangsungan penggunaan kontrasepsi antara ibu yang dikunjungi oleh petugas dengan ibu yang tidak dikunjungi oleh petugas. Probabilitas kelangsungan penggunaan kontrasepsi lebih besar yang tidak dikunjungi oleh petugas kesehatan $(50,22 \%)$ daripada yang dikunjungi oleh petugas kesehatan $(40,56 \%)$.

Responden lebih banyak yang mendapat pelayanan kontrasepsi dari swasta daripada pemerintah yang menunjukkan bahwa program keluarga berencana telah berjalan dengan baik. Meskipun demikian, ternyata kelangsungan penggunaan kontrasepsi tidak juga dipengaruhi oleh tempat ibu memperoleh pelayanan kontrasepsi. Probabilitas kelangsungan penggunaan kontrasepsi antara responden yang mendatangi tempat pelayanan kesehatan pemerintah lebih rendah daripada yang mendapat pelayanan kontrasepsi dari swasta dan lainnya. Berdasarkan informasi yang didapatkan bahwa responden yang datang mengunjungi tempat pelayanan kesehatan untuk mendapatkan informasi tentang kontrasepsi sama dengan jumlah responden yang tidak berkunjung ke tempat pelayanan kesehatan. Hal tersebut menyebabkan kunjungan ke tempat pelayanan kesehatan tidak berpengaruh terhadap kelangsungan penggunaan kontrasepsi. Namun, probabilitas kelangsungan penggunaan kontrasepsi ibu yang berkunjung ke tempat pelayanan kesehatan lebih tinggi daripada yang tidak berkunjung ke tempat pelayanan kesehatan.

\section{Kesimpulan}

Probabilitas kelangsungan penggunaan kontrasepsi hingga 72 bulan pada wanita di Indonesia adalah $50,38 \%$. Umur, jumlah anak dan tempat tinggal tidak berhubungan dengan kelangsungan penggunaan kontrasepsi. Ditemukan hubungan bermakna antara tingkat pendidikan responden dan status pekerjaan responden. Jenis pekerjaan suami dan tingkat ekonomi keluarga tidak berhubungan dengan kelangsungan penggunaan kontrasepsi. Ibu dengan tingkat pendidikan SMP atau < SMP yang bekerja dan suami yang bekerja mempunyai tingkat kelangsungan penggunaan kontrasepsi yang le- bih pendek daripada yang memiliki tingkat pendidikan > SMP dengan status pekerjaan tidak bekerja serta memiliki suami yang bekerja sebagai teknisi/administrasi dan tingkat ekonomi miskin. Tidak ada hubungan antara kunjungan petugas keluarga berencana dan tempat pelayanan kesehatan dengan kelangsungan penggunaan kontrasepsi. Kunjungan akseptor ke tempat pelayanan kesehatan ternyata tidak berhubungan dengan kelangsungan penggunaan kontrasepsi.

\section{Saran}

Dalam pembinaan kepada masyarakat perlu meningkatkan pentingnya arti keluarga berencana dengan menggunakan kontrasepsi sehingga dapat menciptakan keluarga yang berkualitas, baik melalui media cetak maupun elektronik. Dalam materi pelajaran SMA hendaknya dimasukkan materi tentang keluarga berencana yang dikaitkan dengan kesehatan reproduksi atau sistem reproduksi. Untuk paket pendidikan kejar paket A hendaknya dimasukkan materi tentang keluarga berencana. Dalam arahan kesehatan dan keselamatan kerja, hendaknya dimasukkan materi tentang keluarga berencana yang dikaitkan dengan pendidikan yang akan ditempuh anak untuk mendapatkan anak yang berkualitas. Para akseptor hendaknya memiliki kesadaran tentang arti pentingnya keluarga berencana dengan mempertimbangkan jumlah dan jarak kelahiran anak yang satu dengan anak yang berikutnya. Hal ini dimaksudkan untuk menciptakan keluarga bahagia sejahtera serta berkualitas, tentunya dengan 2 orang anak lebih baik. Perlu diteliti harapan jumlah anak yang diinginkan oleh pasangan suami istri serta keterpaparan dengan media dengan kelangsungan penggunaan kontrasepsi.

\section{Daftar Pustaka}

1. Population Reference Bureau. Demografic data and estimates for the countries and regions of the world. New York; 2000.

2. Badan Pusat Statistik. Survei demografi kesehatan Indonesia 20022003. Jakarta: BPS, BKKBN, Departemen Kesehatan RI; 2003.

3. SDKI, 2002-2003.

4. BKKBN. Informasi dasar gerakan keluarga dan pembangunan keluarga sejahtera. Jakarta: BKKBN; 1996.

5. Departeman Kesehatan RI. Buku pedoman petugas fasilitas pelayanan keluarga berencana. Jakarta: Departemen Kesehatan RI; 2006.

6. Hermalin, Albert I. Some observation on the regional of fertility. Mahadevan, K (eds).1986. Fertility and Mortality Theory, Methodologi and EmpiricalIssues. 1986; 351:58-61.

7. Lemeshow, Stanley. Besar sampel dalam penelitian kesehatan. Yogyakarta: Gajah Mada University Press; 1997.

8. Rajagukguk, O, B. Contrceptive choice in Indonesia 1987 \& 1991. Journal of Population. 1995; 1(1):1-19. 